\title{
O ASYLO DA MENDICIDADE E OS PLANOS URBANÍSTICOS DO SÉCULO XIX NO RIO DE JANEIRO
}

\section{The Mendicity Asylum And The 19th Century Urbanistic Plans In Rio De Janeiro}

\section{Eliara Beck Souza}

Programa de Pós-Graduação em Arquitetura - Universidade Federal do Rio de Janeiro eliarabeck@gmail.com

\section{Ana Maria Gadelha Albano Amora}

Faculdade de Arquitetura e Urbanismo - Universidade Federal do Rio de Janeiro aaamora@gmail.com

\section{Resumo}

O objetivo deste artigo é relacionar a edificação do Asylo da Mendicidade no Rio de Janeiro em $1876 \mathrm{com}$ os ideais de razão, ordem e higiene que permearam os planos urbanísticos do século XIX. São abordados o relatório de Beaurepaire Rohan (1843) e o plano da Comissão de Melhoramentos (1876), os quais aliaram preocupações estéticas, de saúde pública e de infraestrutura urbana. Defende-se que, como parte do projeto de modernização proposto, foi construído o Asylo da Mendicidade, um instrumento não só de assistência pública, mas também de manutenção da ordem. Para isso, a edificação deveria ser representante do progresso científico, apresentando os mesmos ideais dos planos urbanísticos, na sua arquitetura neoclássica e no tipo arquitetônico escolhido, o pan-óptico.

\section{Palavras-chave}

Asylo da Mendicidade do Rio de Janeiro, Hospital São Francisco de Assis, Assistência pública.

\section{Abstract}

The purpose of this article is to relate the edification of the Asylo da Mendicidade in Rio de Janeiro in 1876 with the ideals of reason, order and hygiene that permeated the urban plans in the nineteenth century. The report by Beaurepaire Rohan (1843) and the plan of the Improvements Commission (1876) are approached. Their recommendations allied aesthetic concerns, public health and urban infrastructure. As part of this proposed modernization project, the asylum consisted in an instrument not 
only for assistance, but also for the maintenance of the public order. The building should be representative of the scientific progress, with the same ideals of the urban plans in its neoclassical architecture and architectural type, the panoptic.

\section{Keywords}

Asylo da Mendicidade in Rio de Janeiro, Hospital São Francisco de Assis, Public assistance.

\section{Os planos urbanísticos do Rio de Janeiro do século XIX}

Considera-se que o momento da edificação do Asylo da Mendicidade ${ }^{1}$ (Figura 1) em 1876 na Cidade Nova, Rio de Janeiro, é um ponto de convergência da história da arquitetura para a saúde e da história urbana. Os mesmos ideais de razão, ordem e higiene, expressados na arquitetura neoclássica tardia e na concepção espacial em pan-óptico ${ }^{2}$ do asilo, constituíam a justificativa e o objetivo dos planos urbanísticos do Rio de Janeiro no século XIX. Tais planos, como sintetizadores do pensamento de sua época, propunham a modernização do Rio de Janeiro para equipará-lo às cidades europeias e assim, pela intervenção na dimensão física, atingir também a dimensão subjetiva do comportamento da sociedade.

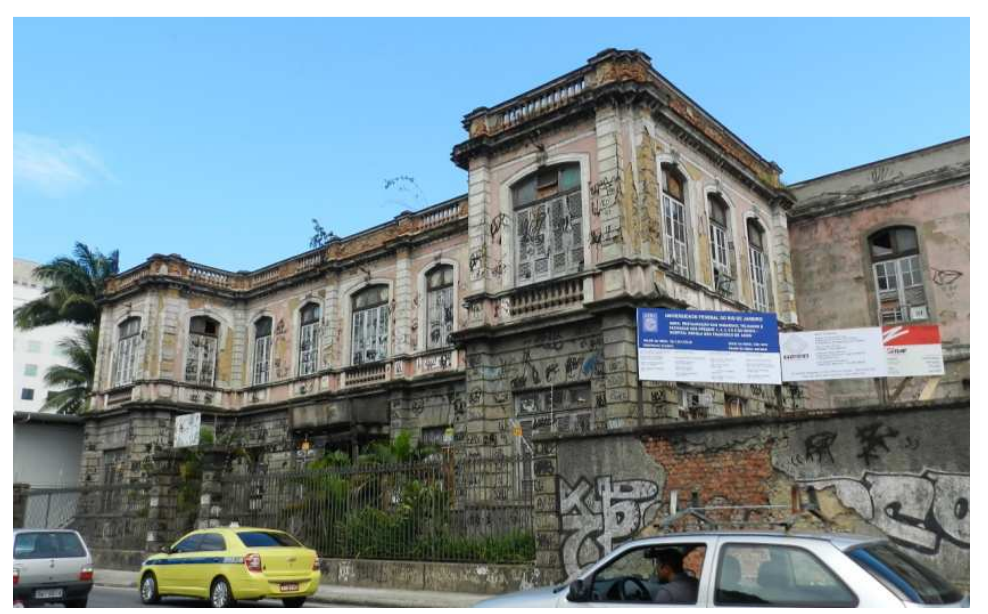

Figura 1 - Asylo da Mendicidade, atual Instituto de Atenção à Saúde São Francisco de Assis.

Fonte: autora, 2012.

\footnotetext{
${ }^{1}$ A edificação se situa na Avenida Presidente Vargas, 2863, Cidade Nova, Rio de Janeiro. Criada inicialmente como asilo, chamou-se Asylo da Mendicidade (1879-1895) e Asilo São Francisco de Assis (1895-1922). Em 1922, foi transformada no Hospital Geral São Francisco de Assis (1922-1946) e posteriormente denominada Hospital Escola São Francisco de Assis - HESFA (1946-2013). Em 2013, seu nome foi alterado para Instituto de Atenção à Saúde São Francisco de Assis.

${ }^{2}$ Empregou-se a grafia pan-óptico conforme o Acordo Ortográfico da Língua Portuguesa de 1990 em vigor desde 2009.
}

URBANA, V.6, no 8, jun.2014 - Dossiê: Cidade e Habitação na América Latina - CIEC/UNICAMP 
O processo de modernização, iniciado com a chegada da Família Real Portuguesa ao Rio de Janeiro em 1808, intensificou-se na passagem da primeira para a segunda metade do século XIX, quando, de acordo com Jaime L. Benchimol (1992), emergiram elementos novos e forças poderosas de renovação no âmbito da cidade escravista. No contexto da segunda Revolução Industrial e do surgimento de uma sociedade capitalista brasileira, implantaram-se ferrovias, novas estruturas portuárias e serviços urbanos, empregando trabalho assalariado.

Ao longo do século XIX, com o adensamento populacional e a intensificação da circulação de mercadorias, fez-se necessária a expansão urbana (PINTO, 2007). Tal expansão ocorreu em direção à Cidade Nova e denotou uma nova prática urbanística de ocupação que se contrapôs às vias estreitas e insalubres da estrutura material da cidade escravista colonial e aplicou um determinado conhecimento acerca da salubridade da cidade como aponta Lúcia Silva (2012, p. 86):

Com as ruas mais largas que davam maior regularidade a estrutura urbana sob a forma de grandes quarteirões e de uma política urbanizadora de incorporação daquele chão à cidade; a região começava a se estruturar a partir de uma nova ordem urbana identificada nos desenhos e nas novas concepções urbanísticas, mas também no sistema fundiário e no parcelamento da terra (SILVA, 2012).

Segundo Fernanda M. Pinto (2007), a região da Cidade Nova apresentou a consolidação de sua malha com vias mais largas e retilíneas na década de 1840 e demonstrou a inserção de novas concepções urbanas que já figuravam no Código de Posturas da Câmara Municipal de 1838. Como também aponta a autora, na segunda seção do código, o título primeiro dispunha sobre o alinhamento de ruas e edificações, informando no primeiro parágrafo que seria obrigação da Câmara levantar os planos para a formação das ruas, praças e edifícios na cidade e no seu termo e, no terceiro parágrafo, exigia que todas as ruas, travessas ou estradas que se abrissem na cidade e em seu termo deveriam ter no mínimo 60 palmos de largura. Havia ainda posturas sobre a limpeza das vias; esgotamento de pântanos, águas infectas e terrenos abertos; estabelecimentos como currais, matadouros e fábricas que pudessem comprometer a qualidade do ar; entre outras que já assinalavam preocupações com a salubridade.

Ao mesmo tempo em que a Cidade Nova se consolidava em meados do século XIX, a cidade velha apresentou um crescimento demográfico acelerado, alta densidade e problemas de salubridade. A proliferação dos cortiços atingiu o entorno do Campo de Santana (PINTO, 2007) e se intensificou com o aumento do fluxo de 
imigrantes portugueses e com o crescimento do número de alforrias dos escravos (CHALHOUB, 2006).

Em 1843, foi apresentado o relatório do engenheiro Henrique de Beaurepaire Rohan, considerado o primeiro plano urbanístico da cidade do Rio de Janeiro (ANDREATTA, 2006). Já na década de 1870, em um contexto de transformações sociais e políticas ainda mais profundas, a cidade tornou-se espaço de intervenção, tendo o Estado como agente (SILVA, 2012). Nesse momento, dois campos distintos de conhecimento apresentaram propostas similares a partir de diferentes argumentos: o Plano de Melhoramentos de 1876, elaborado por engenheiros; e o Plano da Junta de Higiene de 1878 , elaborado por médicos.

\subsection{Relatório Beaurepaire Rohan (1843)}

Henrique Pedro Carlos de Beaurepaire Rohan foi um engenheiro formado pela Escola Militar que permaneceu no exército e atingiu o posto máximo de marechal (TELLES, 1994). À época de apresentação do plano o Visconde de Beaurepaire Rohan era Diretor das Obras Municipais (ANDREATTA, 2006).

O contexto do relatório é o Rio de Janeiro como capital do novo Império do Brasil que apresentava crescimento demográfico, aumento da densidade urbana e uma ainda incipiente presença de serviços urbanos e infraestrutura de transportes. 0 núcleo urbano se concentrava no litoral portuário da Baía de Guanabara limitado pelos morros e brejos circundantes, o que agravava os problemas de salubridade com epidemias recorrentes (ANDREATTA, 2006).

A ordem higiênica e sanitária estava na origem das preocupações urbanísticas. Contribuindo para essa discussão, Verena Andreatta (2006) destaca também que, com o advento do regime constitucional, a polícia urbana se configurou como competência e, portanto, plataforma do poder municipal. Sobre o que afirma:

E deve-se lembrar que a atividade de polícia urbana se identifica ao conceito de ordem pública, cujos elementos característicos, segundo os esquemas liberais dominantes, eram a tranquilidade, a seguridade e a salubridade pública. (ANDREATTA, 2006, p. 87)

O relatório de Beaurepaire, apresentado à Câmara Municipal em 1843, é o primeiro documento a propor uma organização formal para a cidade do Rio de Janeiro depois da Independência, afirma Verena Andreatta (2006). A mesma autora expõe que o plano é um exemplo da aplicação da engenharia militar barroca nas técnicas de urbanização moderna com propostas não só para a cidade construída, mas também 
para futuras áreas de expansão, além de aparentemente intencionar introduzir a malha geométrica hispano-americana na cidade de origem portuguesa. Segundo Margareth Pereira (2010), embora aquém dos padrões científicos atuais, o relatório revolucionou a forma de sistematizar o olhar sobre a cidade, definindo a nova importância que os engenheiros adquiririam nos debates urbanos: "De fato, Rohan manifesta uma firme convicção quanto ao papel ativo e propositivo que as elites técnicas devem ocupar no processo de modernização do país" (PEREIRA, 2010, p. 141).

O documento partiu do diagnóstico da situação fundiária, com a utilização de uma planta cadastral, e buscou corrigir o crescimento desordenado e a insalubridade da cidade por meio de um traçado geométrico (Figura 2) que atendesse aos ideais de modernização e à implantação de infraestrutura urbana. Recomendava para as áreas consolidadas, e também para as áreas de expansão, o alargamento, prolongamento e pavimentação de vias, implantação de praças para mercados, a utilização de calhas nos telhados, calçadas com sarjetas de inclinação adequada para drenagem das águas pluviais, a drenagem do Campo de Santana, implantação de rede de abastecimento de água e canalização do mangue da Cidade Nova. Essa última proposta tinha a intenção de eliminar os miasmas dali provenientes, melhorando a qualidade do ar e permitindo a melhor ocupação da área, o que viria a ocorrer apenas em 1854 com a execução do canal do Mangue pelo Barão de Mauá (PINTO, 2007). Foram propostas 33 ruas para prolongamento, 23 para abertura, 8 praças para melhoria e outras oito para criação (RABHA, 2010). Beaurepaire Rohan, buscando a salubridade e embelezamento, chega a defender a demolição de quase um terço da área urbanizada do Rio de Janeiro (PEREIRA, 2010). Segundo Nina Rabha (2010), seriam afetados 5.657 imóveis ou $40 \%$ do total. 


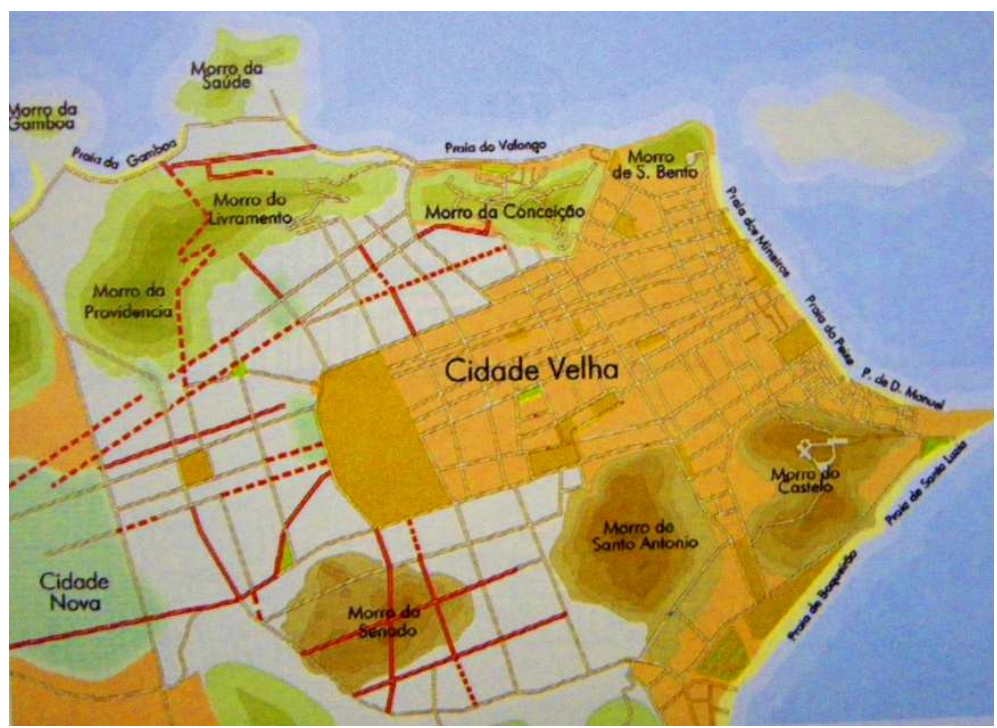

Figura 2 - Traçado proposto pelo Plano de Beaurepaire para a Cidade Nova Fonte: adaptado de ANDREATTA, 2006.

Além disso, o relatório previu um aparato de fiscalização e manutenção das vias de ligação entre o centro urbano e as áreas de expansão para facilitar as transações comerciais. Nesse sentido, Beaurepaire Rohan propôs o Campo de Santana não mais como limite do núcleo colonial, mas como articulador entre a cidade velha e a Cidade Nova, entre os morros do Senado e da Providência, entre a zona produtora do estado e a zona de escoamento. Configurou-se, assim, uma nova centralidade impulsionadora da expansão no Campo de Santana o que se confirmaria na segunda metade do século XIX, entre outros motivos, pelo estabelecimento de marcos institucionais e administrativos do poder naquele local (ANDREATTA, 2006; PINTO, 2007).

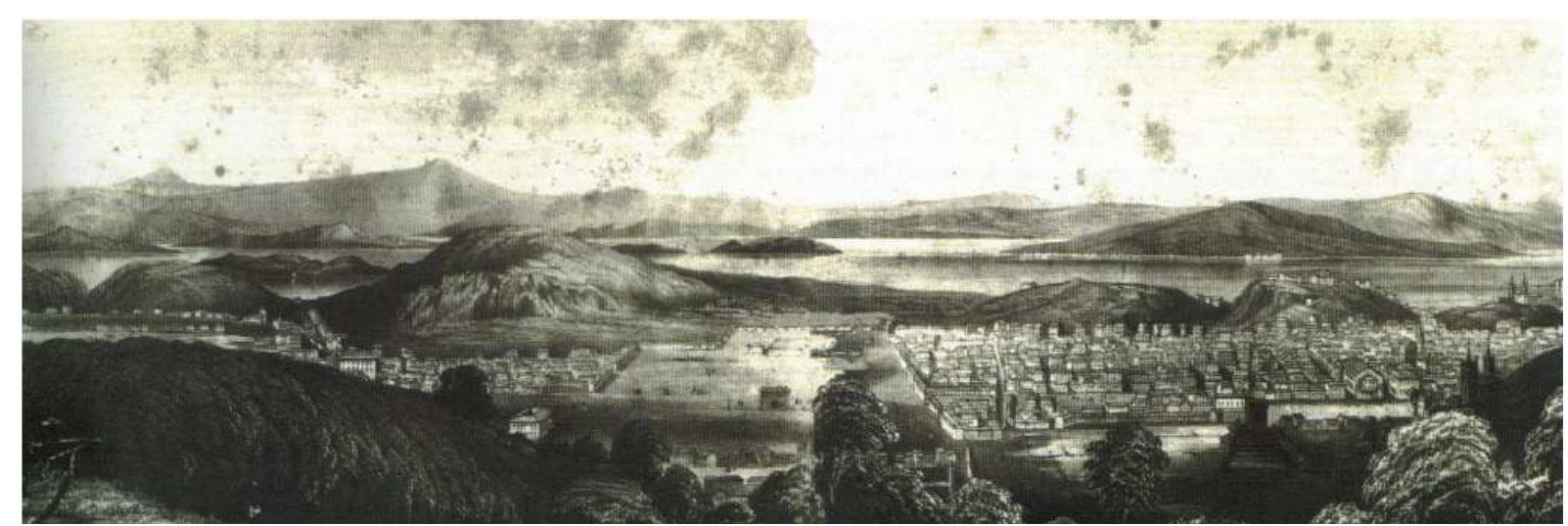

Figura 3 - A Cidade Velha à direita e a Cidade Nova à esquerda, com o Campo de Santana ao centro, em 1840.

Fonte: ANDREATTA, 2006.

Segundo Nina Rabha (2010), a análise de Beaurepaire Rohan foi sendo apropriada ao longo do tempo e as recomendações nortearam as ações posteriores da 
Câmara Municipal como abertura de vias e melhorias de estradas. Embora não tenha sido executado completamente, algumas diretrizes do plano se consolidaram na estrutura da Cidade Nova, na canalização do mangue e na nova centralidade exercida pelo Campo de Santana. Salienta-se ainda que uma das propostas executadas foi a transferência do Matadouro da Praia de Santa Luzia, um "imundo telheiro, cercado de imundíssimas barracas, cujas evaporações produzem enfermidades endêmicas nas suas circunvizinhanças" (ROHAN, 1843 apud ANDREATTA, 2008, p.4) lá estabelecido desde 1777, para São Cristóvão. A antiga construção do matadouro em Santa Luzia foi utilizada para abrigar o albergue de mendigos, um dos antecedentes da criação do Asilo de Mendicidade. Pode-se afirmar que o Relatório de Beaurepaire Rohan, por seu pioneirismo em uma formulação mais abrangente além de intervenções pontuais, possibilitou os planos seguintes como o Plano da Comissão de Melhoramentos de 1876 e o Plano da Junta de Higiene de 1878.

\subsection{Plano da Comissão de Melhoramentos (1875-1876) e o Plano da Junta Médica (1878)}

O Plano da Comissão de Melhoramentos constitui-se de dois relatórios elaborados em 1875 e 1876 pelos engenheiros Francisco Pereira Passos, Jerônimo Rodrigues de Morais Jardim e Marcelino Ramos da Silva. Os documentos recuperam as ideias de Beaurepaire Rohan e, segundo Andreatta (2008), introduzem as ferramentas da urbanística contemporânea: alinhamentos, ordem edificatória figurativa e infraestruturas dos novos serviços urbanos.

O contexto do plano era um Rio de Janeiro consolidado como potência mercantil e receptor de imigrantes para substituição da mão de obra escrava, mas que ainda mantinha um centro desordenado, de densidade excessiva e precária infraestrutura, onde habitava grande parte de sua população de 235 mil pessoas (ANDREATTA, 2008).

Deve-se ainda acrescentar a recorrência sistemática de epidemias. Nesse sentido, a febre amarela compareceu com um primeiro surto em 1850, com 4160 vítimas fatais, para retornar com dois surtos graves em 1873 e 1876, causando a morte de 3659 e 3476 pessoas respectivamente (CHALHOUB, 2006). Houve ainda epidemias de cólera em diversas partes do Império em 1855 e 1856.

Contribuindo para se compreender o contexto dos planos e das significativas mudanças em curso, Lúcia Silva (2012, p. 132) afirma: 
A década de 1870 é tida por vários autores (Abreu, 1988; Benchimol, 1992; Chalhoub, 2003; Carvalho, 1994) como divisor de águas, não só porque nos anos de 1870 a materialidade da cidade passaria a ser o laboratório de uma nova forma de pensar a intervenção na urbe, mas porque os problemas que assolavam a cidade estavam definitivamente deixando de ser da esfera privada para ser da alçada do Estado por conta da vitória da Lei do Ventre Livre, promulgada em 1871. O que interessa aqui para pensar a cidade são dois elementos intrínsecos à lei. O primeiro refere-se à derrota da noção senhorial que até então permeava aquela discussão, na medida em que essa concepção portava em si a ideia de um Estado não interventor em assuntos de ordem privada, tal como era pensada a escravidão; e o segundo a própria noção de escravidão (SILVA, 2012).

O Plano de Melhoramentos de 1876, ainda que não faça qualquer menção ao escravismo, já concebe a cidade fora dos moldes escravistas em um discurso relacionado ao ordenamento do caos urbano e ao progresso da cidade (SILVA, 2012).

O primeiro relatório de 1875 tratava da região da Cidade Nova, juntamente com o Andaraí, o Engenho Velho e São Cristóvão, áreas de expansão desde o início do século XIX. Para Fernanda M. Pinto (2007), o Plano da Comissão de Melhoramentos se aproximava do relatório de Beaurepaire Rohan por suas preocupações com as condições higiênicas e com a estética urbana, porém era mais detalhado, com uma melhor justificativa técnica e com maior alcance territorial.

As metas da Comissão, como descritas por Margareth Pereira (PEREIRA, 2010), eram articular iniciativas urbanas já aprovadas, melhorando as condições higiênicas, facilitando a circulação e embelezando e harmonizando as construções urbanas. Segundo Verena Andreatta (2008), os relatórios da Comissão de Melhoramentos podem ser resumidos sob quatro aspectos: a definição de uma estrutura urbana para a expansão da cidade, usando a técnica de alinhamentos; a fixação de algumas normas reguladoras da edificação, coerentes com o uso do instrumento urbanístico do traçado; a proposta de um esquema de drenagem das correntes afluentes das bacias do canal do mangue; e um programa de obras para formatação da frente portuária setentrional e da frente marítima meridional.

Ainda que não fossem previstas intervenções na cidade velha de padrão colonial por falta de recursos financeiros e de regulamentação, necessários a desapropriação urbana (ANDREATTA, 2006; BENCHIMOL, 1992), no plano se propunha a renovação da área central pelo deslocamento para fora dela das classes populares, por meio da expansão urbana possibilitada por bondes e trens e pelas amplas avenidas (ANDREATTA, 2006). 
A proposta central para a região da Cidade Nova era a finalização e prolongamento do Canal do Mangue "que no estado incompleto e de abandono em que se acha, é um foco permanente de infecções miasmáticas" (BENCHIMOL, 1992), saneando os terrenos alagadiços do entorno. Mesmo considerando a totalidade territorial do plano, a canalização era fundamental por apoiar a estrutura urbana e viabilizar o estabelecimento de um porto moderno com a criação de um canal navegável acompanhado por vias e um ramal ferroviário da Estrada de Ferro Dom Pedro II, desviando o trânsito de mercadorias do centro de ruas estreitas e congestionadas (ANDREATTA, 2008). A operação de canalização foi justificada pela Comissão de Melhoramentos tanto por motivos de saneamento quanto por razões de preparação de áreas para expansão urbana, analogamente às propostas para arrasamento dos morros de Santo Antonio, do Senado e do Castelo (ANDREATTA, 2008) que ocorreriam apenas no início do século $X X$.

O plano de 1878 , por sua vez, foi elaborado pela comissão formada pelos médicos José Pereira Rego, o Barão de Lavradio, Manoel Pacheco da Silva, Manoel Pereira da Silva Continentino, João Baptista dos Santos, Luiz Bandeira de Gouvea e Pedro Afonso de Carvalho, e intitulado "Bases apresentadas pela Junta de Higiene para melhoramentos sanitários".

Naquele momento, por meio da medicina social, os médicos extrapolaram da escala individual para a escala coletiva e urbana, tratava-se não só da saúde do corpo e dos hábitos degenerativos das pessoas, mas também da salubridade das residências e da cidade. Suas formulações derivavam da medicina hipocrática e de novas ciências físicoquímicas e sociais, envolvendo desde o movimento das populações até o dos astros, e objetivavam restaurar o equilíbrio do organismo urbano (BENCHIMOL, 2010). Ao inventariar os componentes insalubres, eram elencados aspectos geográficos do território:

Os pântanos eram considerados os principais focos de exalação de miasmas, os gases pestíferos que, supunha-se, causavam as doenças Os morros impediam a circulação dos ventos capazes de dissipá-los. Deles desciam as águas dos rios e das chuvas que estagnavam na planície, sobre a qual se erguia a maior parte construída da cidade. (BENCHIMOL, 2010, p. 173)

Além desses componentes físico-naturais, havia os componentes sociais inventariados como a insalubridade das habitações coletivas "que funcionavam como fermentadores ou putrefatórios, liberando nuvens de miasmas sobre a cidade" (BENCHIMOL, 2010, p. 173) pela qual eram responsáveis tanto as sujeiras físicas e morais dos pobres que ali se amontoavam quanto a ganância dos proprietários dos 
imóveis. Eram condenados ainda usos como matadouros, açougues, mercados, fábricas, hospitais e prisões, assim como hábitos como o acúmulo de lixo nas ruas e praias e uso de valas a céu aberto. Segundo Jaime Benchimol (2010, p. 174), ao inventariar esses pontos, os médicos definiram as questões que os engenheiros deveriam combater:

\begin{abstract}
A medicina social que praticavam mostrou-se eficaz sobretudo na sedimentação de um discurso sobre o urbano cujos argumentos se repetem até o começo do século XX em tudo que escreveram os engenheiros, políticos e outros atores sociais. Esse discurso infiltrou-se no senso comum das elites e das camadas médias, que nas décadas de 1870 e de 1880 já constituíam influente opinião pública favorável a tudo que viesse a transformar a capital do Império em uma metrópole salubre e moderna (BENCHIMOL, 2010).
\end{abstract}

Ainda que $o$ autor acredite que alguns historiadores superestimam a influência desse grupo nas decisões do Estado e do capital, afirma que contribuíram para as primeiras leis que pensavam a cidade e ajudaram a promover mudanças nos padrões de sociabilidade e nas formas de organização do espaço, mesmo que sem deter as epidemias (BENCHIMOL, 2010).

\title{
2. Reforma urbana como reforma social
}

Dos autores citados, tanto Benchimol (1992) quanto Andreatta (2006) afirmam que esses planos são referenciais da urbanística de sua época, cujas propostas prenunciavam o discurso sanitarista e modernizador que se afirmaria nas intervenções do início do século XX, sob o governo do Engenheiro Pereira Passos, membro da Comissão de Melhoramentos.

Como já mencionado, o objetivo desse artigo é ir além ao relacionar o pensamento aplicado aos planos com outras intervenções e transformações que ocorriam no Rio de Janeiro do século XIX, especialmente com a edificação do Asylo da Mendicidade em 1876. Para isso, buscou-se identificar os discursos dos dois principais grupos que intervinham na cidade: médicos e engenheiros.

Segundo Andreatta (2006), as preocupações sociais que permearam os planos moldaram a noção de Saúde Pública que, por sua vez, ocasionou a formação de uma tradição disciplinar na medicina e na engenharia: a sanitária, que estaria na origem da urbanística. Já Maurício de A. Abreu (1999) enxerga dois momentos no desenvolvimento dessa tradição. O primeiro, higienista, sistematizado pelos médicos na Europa do século XVII, que estabeleceu uma relação íntima entre a "deterioração" ou "corrupção" do meio natural, e o surgimento dos surtos epidêmicos que guiou a reflexão urbana brasileira da segunda metade do século XIX. E o segundo, sanitarista, URBANA, V.6, no 8, jun.2014 - Dossiê: Cidade e Habitação na América Latina - CIEC/UNICAMP 
sustentado pelas regras científicas do positivismo e defendido pelos engenheiros. A transição do verbo higienizar para o sanear ocorreu após a revolução bacteriológica pasteuriana em 1880 que desacreditou rapidamente os postulados do higienismo e, em especial, a teoria dos miasmas (ABREU, 1999).

De acordo com Lúcia Silva (2012), os engenheiros interferiam na cidade de forma restrita, apenas quando era necessário assegurar o escoamento da produção por meio de portos, pontes, estradas e ferrovias, ou ainda, resolver problemas da infraestrutura urbana incipiente, como as crises de abastecimento de água. Os médicos, por sua vez, eram convocados para tentar identificar e solucionar as questões relacionadas à salubridade urbana especialmente em períodos de recorrência de epidemias de febre amarela, cólera e varíola.

Apesar de a cidade ser pensada por esses dois grupos diferentes (médicos e engenheiros) com motivações a princípio distintas (sanitárias e econômicas), as ações na materialidade se equivaliam. Como exemplifica a mesma autora (SILVA, 2012), ambos os grupos de profissionais propunham a ampliação das vias seja para melhorar a aeração ou o trânsito de cargas.

Inicialmente, os engenheiros utilizavam um discurso neutro e científico de ordenamento para justificar suas intervenções urbanas, enquanto os médicos apontavam a pobreza e os aspectos morais do modo de vida da população como agentes de insalubridade que precisavam ser combatidos, ao fazê-lo, os dois grupos traduziam os problemas urbanos ao mesmo tempo em que criavam novas demandas sociais por higiene, infraestrutura e ordenamento urbano (SILVA, 2012). Esse olhar político consolidaria uma leitura que avaliava e valorava hábitos sociais. Assim, essas ações, além de terem por objetivo a criação de uma cidade salubre e ordenada, buscavam, pela intervenção na materialidade, uma revolução econômica e social que geraria uma nova sociedade.

A Medicina torna-se então uma ciência social e política ao procurar agir preventivamente, eliminando as causas das doenças que não mais se centravam no indivíduo, mas no ambiente que o circundava (MACHADO et al, 1978). Segundo Benchimol (1992), a medicina social tratava o espaço urbano como circulação desordenada de elementos responsável pela degeneração física e moral da população. A declaração do médico José Pereira Rego, Barão de Lavradio, vereador e presidente da Junta Central de Higiene seguia essa mesma lógica (CHALHOUB, 2006, p. 34):

O aperfeiçoamento e progresso da higiene pública em qualquer país simboliza o aperfeiçoamento moral e material do povo, que o habita; é o espelho, onde se refletem as conquistas, que tem ele alcançado no caminho da civilização. 
Tão verdadeiro é o princípio, que enunciamos, que em todos os países mais cultos os homens, que estão à frente da administração pública, procuram, na órbita de suas atribuições, melhorar o estado da higiene pública debaixo de todas as relações, como um elemento de grandeza e prosperidade desses países... Entre nós, porém, força é confessar que as municipalidades [... dela] têm-se esquecido um pouco dos melhoramentos materiais do Município e do bem-estar, que deles pode resultar a seus concidadãos, tanto que sobre alguns pontos essenciais e indispensáveis ao estado higiênico, parece que ainda nos conservamos muito próximos aos tempos coloniais (CHALHOUB, 2006, p. 34).

Nela, como aponta Chalhoub (2006), estavam presentes ideias que em breve se tornariam senso comum entre os administradores das cidades no Brasil das últimas décadas do século XIX. Entre elas, a oposição entre 'civilização' e 'tempos coloniais' e a solução de problemas sanitários como caminho para o 'aperfeiçoamento moral e material', que conduziria a nação à 'grandeza' e 'prosperidade' a semelhança dos 'países mais cultos'. Desse modo, a política deveria se submeter à técnica, não havendo forma científica ou neutra de resolver os problemas da cidade e da sociedade. Ou como afirma o autor:

Tal ordem de ideias iria saturar o ambiente intelectual do país nas décadas seguintes, e emprestar suporte ideológico para a ação 'saneadora' dos engenheiros e médicos que passariam a se encastelar e acumular poder na administração pública, especialmente após o golpe militar republicano de 1889. Mas insistir na importância de conceitos como 'civilização', 'ordem', 'progresso', e outros afins - os correlatos como 'limpeza' e 'beleza', e os invertidos tais como 'tempos coloniais', 'desordem', 'imundície' etc. - não nos leva muito além da transparência dos discursos, da observação da forma como eles se estruturam e daquilo que eles procuram afirmar na sua própria literalidade, e através da repetição ad nauseam. O que se declara, literalmente, é o desejo de fazer a civilização europeia nos trópicos; o que se procura, na prática, é fazer política deslegitimando o lugar da política na história. (CHALHOUB, 2006, p. 34)

Esse processo civilizatório e de busca pela europeização de hábitos sociais e padrões urbanos do Rio de Janeiro passava ainda pela classificação das classes perigosas à manutenção da ordem pública e à organização do trabalho. Tais classes perigosas foram então diretamente relacionadas às classes pobres o que Chalhoub (2006) define como "teoria da suspeição generalizada". Os pobres carregariam vícios, os vícios produziriam malfeitores e os malfeitores seriam perigosos, do que deriva que os pobres seriam perigosos, especialmente os ociosos. Tal entendimento pode ser percebido no debate parlamentar de maio de 1888, citado por Sidney Chalhoub (2006, p. 21): 
As classes pobres e viciosas, diz um criminalista notável [identificado por Chalhoub como o M. A. Frégier, alto funcionário da polícia de Paris], sempre foram e hão de ser sempre a mais abundante causa de todas as sortes de malfeitores: são elas que se designam mais propriamente sob o título de classes perigosas -; pois, quando mesmo o vício não é acompanhado pelo crime, só o fato de aliar-se à pobreza no mesmo indivíduo constitui um justo motivo de terror para a sociedade. $O$ perigo social cresce e torna-se de mais a mais ameaçador, à medida que o pobre deteriora a sua condição pelo vício e, o que é pior, pela ociosidade (CHALHOUB, 2006).

O mesmo autor afirma que é possível perceber nesses debates parlamentares a tendência de associar o gosto pelo trabalho ao bom cidadão, assim o indivíduo que vive na pobreza por não conseguir acumular riquezas com o esforço de seu trabalho é, consequentemente, suspeito de não ser um bom trabalhador. A ociosidade é então considerada o pior dos vícios e uma ameaça à ordem social vigente (CHALHOUB, 2006).

Segundo Jaime Benchimol (1992), entre 1850 e 1870, a crise de habitações para as classes mais pobres da população e a multiplicação dos cortiços emergiram como traços característicos da vida urbana no Rio de Janeiro. Margareth Pereira (2010, p. 152) afirma que, no fim do século, as camadas mais pobres se fixam no centro que vinha sendo abandonado, sobretudo a população negra se amontoava nos cortiços: "Como já acusava Luiz Rafael Vieira Souto, na esteira das lutas por maior distribuição de renda e justiça social: Tornara-se difícil ser pobre no Rio de Janeiro".

Junto a isso, é possível afirmar que também era grande a população de moradores de rua, que, como visto, apresentava especial perigo social na visão da época por ser ociosa, vivendo da mendicância. Então, tornou-se necessário identificar e combater esses componentes perigosos com vigilância e controle (MACHADO et al, 1978). De acordo com Jaime Benchimol (1992), a administração municipal não se propunha a resolver o problema dos moradores de rua, buscando apenas remover da cidade a disfunção que a enfeava e enclausurá-la na delegacia ou num asilo.

Assim, para a modernização, ordenamento urbano e ainda para o controle do perigo representado pela ociosidade, fez-se urgente o estabelecimento de uma instituição para acolhimento da população pobre e sem residência fixa que vagava mendigando pela cidade. Essa necessidade era reivindicada nos documentos oficiais e também nos jornais:

Requeiro que officie ao governo, pedindo-Ihe providencias contra os mendigos e vadios que vagão a toda a hora do dia pelas ruas e praças da cidade e a 
noite se amontoão n'alguns lugares publicos onde praticão desordens e obscenidades. ${ }^{3}$

Seja como for, o Rio de Janeiro necessita um asylo de mendicidade e um recolhimento para as vagabundas... Porém que não se assemelhem com a cadeia do Aljube... Nem mesmo com a correcção... Quando chegará o dia de se tratar da reforma dos presos: e de obrigar ao trabalho esse enxame de mendigos e mendigas, de gente sem profissão e de vagabundas que abundão por essas ruas! Não se nos responda que é fructa de todos os paizes. Embora; já é tempo de tomarem-se as medidas conducentes para certos estabellecimentos, que contribuem á morigerar a sociedade e corrigir os abusos dos máos costumes. (ESCÂNDALO, 1852, p. 3)

Tenho lido alguns artigos no seu jornal a respeito do deploravel estado dos mendigos do Rio de Janeiro, que vivem quasi abandonados das vistas beneficas das autoridades, e só a custa da caridade publica se sustentam pelas ruas, com grave compromettimento da moralidade [...] Não duvido pois que no Brasil se podesse sem grande custo edificar um asylo para os mendigos, comtanto que houvesse um homem humanitário que se dispozesse a levar a effeito uma obra tão necessaria e tão digna da nação brasileira. 0 imperador do Brasil que se caracterisa pelo seu espirito de caridade e beneficiencia, estou certo que seria o primeiro a coadjuvar e a proteger com o prestigio do seu augusto nome uma obra que tivesse por fim melhorar a triste condição dos indigentes que percorrem inanidos de frio e fome as ruas da populosa capital do seu império. (A MENDICIDADE, 1856, p. 2)

\section{Edificação do Asylo da Mendicidade (1879)}

Em 1854, o Ministro e Secretário de Estado dos Negócios da Justiça, Conselheiro José Tomás Nabuco de Araújo, e o Chefe de Polícia, Desembargador José Joaquim de Siqueira, decidiram criar um albergue de mendigos para controlar "a situação calamitosa da mendicância de rua" (SILVA JR, 2000, p. 35). O antigo matadouro de Santa Luzia foi preparado de forma provisória para abrigar setenta indivíduos a partir do seguinte regulamento:

10 que durante a noite sejam ahi recolhidos todos os mendigos que forem encontrados nas ruas, praças publicas e adros de igrejas;

$2^{\circ}$ que os que forem encontrados doentes sejam logo recolhidos á Santa Casa de Misericórdia;

30 que os que puderem trabalhar sejam logo enviados para a Casa de Correç̧ao. (ASSISTÊNCIA, 1922, p. 448)

Por esse primeiro regulamento, já é possível perceber que o albergue de mendigos fazia parte de uma rede de instituições de assistência pública, entre elas a

\footnotetext{
${ }^{3}$ Arquivo Geral da Cidade do Rio de Janeiro (AGCRJ). Códice 46.2.90. Nota não oficial, sem identificação do remetente ou destinatário, de 09 jun. 1841.
} 
Santa Casa de Misericórdia e a Casa de Correção. A partir do terceiro enunciado da citação, pode-se inferir ainda que os mendigos que possuíam condições de trabalhar eram tratados como malfeitores por sua ociosidade ao serem enviados para a Casa de Correção.

Em 1855, após a epidemia de cólera, os mendigos passaram a ser mantidos reclusos e tornou-se responsabilidade do Estado sua alimentação e vestuário. Eram internados no Asylo da Mendicidade, "mendigos cegos, aleijados, inválidos ou accommettidos de moléstias incuráveis" (ASSISTÊNCIA, 1922, p. 449) indesejados na Santa Casa de Misericórdia e ainda alienados 'mansos' que fossem recusados no Hospício Dom Pedro II.

Como relatado no documento sobre a Assistência Pública e Privada do Rio de Janeiro, o estabelecimento já se encontrava superlotado, chegando a abrigar 329 indivíduos, e era inadequado:

[...] a verdade é que, decorridos 20 annos de existência, não passava ainda a Albergaria de uma tentativa, não podendo positivamente continuar naquelle acanhado edifício, de propriedade particular, constantemente reclamado pelo dono e sem proporções para o seu fim. (ASSISTÊNCIA, 1922, p.449)

Em 1875, foi publicada a lei de orçamento para os anos de 1876-1877, destinando a verba de cem contos de réis para a construção de um asilo (BRASIL, 1875). No mesmo ano, um aviso do Ministério dos Negócios da Justiça ao conselheiro e Diretor-Geral da Diretoria dos Negócios da Justiça, André Augusto de Pádua Fleury definiu:

Convindo organisar trabalhos preparatorios para a reforma completa das nossas prisões no intuito de se adoptar o systema que melhor combine os meios de intimidação com os de correcção do condemnado, o governo imperial encarrega a V.S. de visitar os principaes estabelecimentos penitenciarios da Belgica, Hollanda, França, Italia e especialmente as prisões da Inglaterra, Irlanda, Allemanha e Suissa. [...] e apresentará tambem um plano de asylo de menores desvalidos, vadios ou mendigos. Offerecerá um projecto de regulamento para deposito de mendicidade com planta e orçamento do edificio respectivo. Para auxiliar a V.S. É nesta data nomeado o architecto Heitor Rademaker Grunewald, que o acompanhará nas visitas dos estabelecimentos penitenciarios e correccionaes, incumbido da parte relativa á construcção e architectura dos mesmo estabelecimentos. (PRISÕES..., 1875, grifo nosso)

André Augusto de Pádua Fleury nasceu em Cuiabá em 18 de agosto de 1830, filho do Tenente Antonio de Pádua Fleury e de Dona Augusta Rosa Gandel. Graduouse em 1853 no curso de ciências sociais e jurídicas em São Paulo. Após trabalhar 
como juiz municipal em Goiás, retornou ao Rio de Janeiro para trabalhar na Diretoria de Negócios da Justiça, chegou a ser diretor-geral e conselheiro do Imperador. Foi nesse período que realizou a viagem à Europa para pesquisar sistemas penitenciários, representando o Brasil no Congresso Penitenciário Internacional em Estocolmo em 1878. Participou também da Comissão Inspetora da Casa de Correção da Corte em 1874. (BLAKE, 1883)

O arquiteto, às vezes citado como engenheiro, Heitor Rademaker Grunewald é de biografia pouco conhecida (SOBRAL FILHA, 2009). As informações sobre sua atividade profissional se restringem à participação em obras de estradas e estações ferroviárias (TELLES, 1994) e de um projeto não executado para o Campo da Aclamação com seu irmão mais velho Jorge Rademaker Grunewald (SEGAWA, 1996). Apesar de algumas vezes Heitor ser citado como autor do projeto de reforma da Estação de Ferro Pedro II em 1870, Pedro Carlos da Silva Telles (1994) e Sergio S. Morais (MORAIS, 2002) atribuem essa obra ao seu irmão Jorge, arquiteto formado pela Escola de Belas-Artes de Paris (PEREIRA, 2002).

O plano, apresentado pelo arquiteto, empregava a configuração radial. O tipo pan-óptico era expressão arquitetônica concreta dos ideais de modernização e ordem que permeavam as reformas urbanas do período. A construção planejada pelo filósofo e jurista Jeremy Bentham, em 1785, apresentava disposição circular com celas em toda sua periferia, abertas para o interior e exterior, e uma torre de inspeção central de grandes janelas cobertas por persianas, a fim de permitir ao vigia visibilidade total sem ser percebido (BENTHAM, 2000).

Essa disposição arquitetônica tinha como objetivo responder a um problema político, reduzindo a desordem, o amontoamento, a insalubridade e a imoralidade das instituições de reclusão como apontado por Machado et al (1978, p 323):

Com o Panopticon não se trata mais simplesmente de excluir um grupo de pessoas da sociedade, enclausurando-o em um espaço de desordem, de confusão, de banimento. Ele é um operador, um instrumento político, que dá ao poder maiores capacidades de se exercer aumentando sua força através da constituição de um espaço planificado, ordenado, dividido, bem distribuído (MACHADO et al, 1978).

Como discorreu Michel Foucault (2004), o Pan-óptico de Bentham extrapolou a edificação e consistiu em modelo para a reforma moral da sociedade por meio da existência da vigilância integral e onipresente. Para o mesmo autor, a consequência mais importante é o efeito consciente e permanente de vigilância, a 'máquina arquitetural' cria e sustenta uma relação de poder. 
Anthony Vidler (1987) também cita o componente utilitário do pan-óptico ao afirmar que Bentham utilizou-se do espaço e de sua arquitetura como produtoras de um estado mental, a estética se torna um instrumento da utilidade, da função.

Assim, o emprego desse tipo arquitetônico objetivou disciplinar o espaço externo ao informar que toda desordem seria punida, tratada e curada (SILVA JR., 2000) ao mesmo tempo em que regulava o espaço interno pela vigilância e classificação. Além disso, já existiam naquele momento críticas ao 'aspecto ornamental' do Hospício Pedro II e a pouca classificação que suas instalações 'terapeuticamente insuficientes' permitiam: por sexo, classe social e temperamento tranquilo ou agitado (MACHADO et al, 1978). Dessa forma, seria lógico propor um modelo mais adequado a vigilância e separação dos internos por sexo e idades e que representasse desde sua arquitetura o processo de modernização que se concretizava na cidade e, como se esperava, na sociedade.

Salienta-se que havia um precedente da utilização do pan-óptico, pois o projeto para a Casa de Correção da Corte (Figura 3), anterior ao asilo, já previa uma planta de quatro raios com oitocentas celas em torno de um edifício central da administração e capela (MACHADO et al, 1978), porém a construção iniciada em 1834 teve concluída, seis anos mais tarde, apenas o primeiro raio com dois pavimentos, diferentemente dos quatro andares projetados. O restante da construção caminhou em passos lentos e descaracterizou-se do projeto original, que nunca chegou a ser totalmente concluído (SOBRAL, 2009). Sobre a Casa de Correção, é importante ainda destacar sua localização no Catumbi que, segundo relatório da Comissão Inspetora, era lugar 'mais conveniente e sadio' ainda próximo a cidade junto a um canal que se comunica com o mar, facilitando o transportes de materiais e mantimentos (MACHADO et al, 1978). 


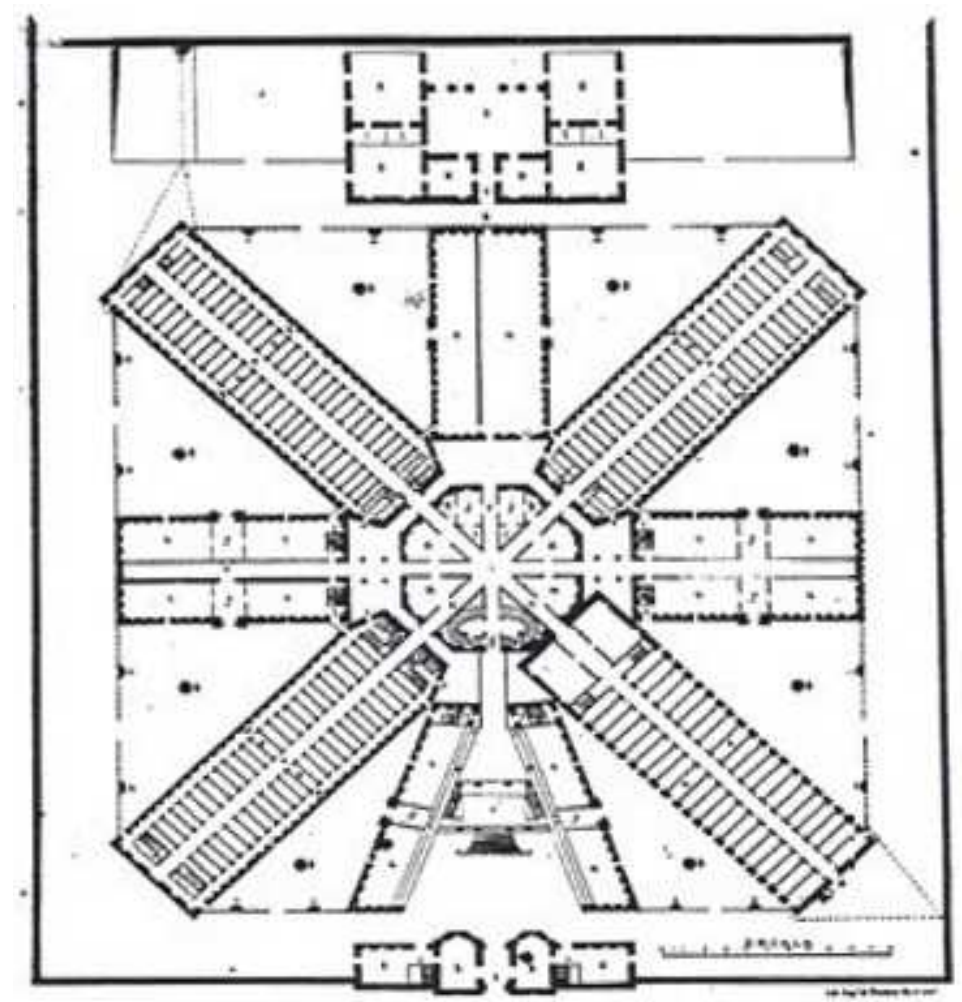

Figura 3 - projeto da Casa de Correção da Corte. Fonte: SOBRAL, 2009.

Após a apresentação do projeto do Asylo de Mendicidade pelo arquiteto Heitor Rademaker Grünewald, que também dirigiu as obras, foi escolhido para a construção o terreno da Rua Visconde de Itaúna, pertencente à Casa de Correção, a qual forneceu material e pessoal para a obra, uma vez que o orçamento de cem contos de réis era insuficiente para a execução do projeto. Parte do terreno fora doado pelo Barão de Pirassununga (AGUINAGA, 1977). O terreno, localizado na Cidade Nova, antiga área de mangue, cumpria ainda a recomendação de afastar das áreas centrais densamente ocupadas esse tipo de estabelecimento, por sua caracterização como emanadora de doenças.

A pedra fundamental do Asilo da Mendicidade foi lançada em 6 de agosto 1876 na presença da Princesa Imperial Isabel, então Regente; do Príncipe Luis Felipe D'Orleans, Conde d’Eu; do ministro e secretário dos negócios da Justiça conselheiro Diogo Velho Cavalcanti de Albuquerque; do vigário-geral reverendo Monsenhor Felix Maria de Freitas Albuquerque; do chefe de polícia Miguel Calmon du Pin e Almeida; e do diretor da Casa de Correção Luiz Vianna de Almeida Valle (ASYLO..., 1876).

Em 10 de julho de 1879, o Asilo da Mendicidade foi inaugurado pelo Imperador Dom Pedro II ainda inacabado. Estavam prontas apenas a administração, dois pavilhões radiais, a cozinha, instalações sanitárias e as canalizações de gás, água 
e esgoto (ASSISTÊNCIA, 1922). A direção do asilo coube ao Chefe de Polícia, até que fosse formulado o respectivo regulamento, o que ressalta que a função do asilo não era meramente assistencial e caridosa, mas também ordenadora.

A parte edificada do Asilo permitiu disponibilizar cento e vinte vagas para internos, porém foram transferidos para lá os duzentos e sessenta indigentes que já se encontravam no albergue do antigo Matadouro de Santa Luzia, bem como velhos e alienados que estavam na Casa de Detenção (ASSISTÊNCIA, 1922). Assim, apesar das intenções de ordenamento e modernização, o Asilo iniciou sua história incompleto, superlotado, sem funcionários, sem verba suficiente e em condições inadequadas, abrigando mais do que o dobro de sua capacidade. Devido a essa situação, instituiuse em 1880 um regulamento provisório que definia:

O Asylo será exclusivamente destinado aos indivíduos dos dous sexos que, não podendo trabalhar, andassem pelas ruas a implorar a caridade pública; nenhum mendigo seria admittido si não enviado pelo Chefe de Polícia. 0 medico visitaria pela manhã o estabelecimento, fazendo recolher á enfermaria ou remover para o Hospital da Misericordia ou para o Hospital da Saude os doentes de moléstia contagiosa ou os que, por falta de conveniente dieta, não pudessem ser tratados no Asylo; bem assim, examinaria e trataria os alienados. Os asylados teriam direito a certos e determinados cuidados hygienicos e nos dias uteis se applicariam a alguns trabalhos. O mendigo ou alienado que chegasse a poder trabalhar ou tivesse pessoa que se obrigasse a mante-lo seria despedido do Asylo, precedendo proposta. O estabelecimento seria franqueado ao publico todos os domingos e quarta-feiras, das 10 ás 12 da manhã. (ASSISTÊNCIA, 1922, p. 450)

Esse franqueamento das instalações ao público pode ser relacionado com a afirmação de Michel Foucault (2004) de que o fechamento do pan-óptico não excluiria a presença do exterior, sendo submetido a inspeções aleatórias e incessantes também por parte de qualquer membro da sociedade. Dessa forma, o dispositivo disciplinar seria democraticamente controlado.

Foi somente em 1884 que entrou em vigor o regulamento definitivo que admitia quatro classes de internos: menores de catorze anos abandonados; indigentes, velhos e incapazes dependentes da caridade; os indigentes que se apresentassem espontaneamente e comprovassem sua situação; e os alienados que não fossem recebidos no Hospício Dom Pedro II. Criou-se também a Associação Protetora do Asilo da Mendicidade que teve por objetivo angariar donativos, possibilitando a continuidade das obras e a execução dos três pavilhões radiais posteriores, que foram novamente interrompidas e somente finalizadas em 1892 (ASSISTÊNCIA, 1922), configurando a planta de partido radial com um volume central 
conectado por passarelas radiais a cinco pavilhões de dois pavimentos e ainda com um bloco principal de entrada (Figura 4). Esse possui fachadas com maior preocupação estética de inspiração neoclássica com revestimento em cantaria de gnaisse em todo o térreo. Os blocos pavilhonares são mais simples, apresentando menos elementos decorativos.

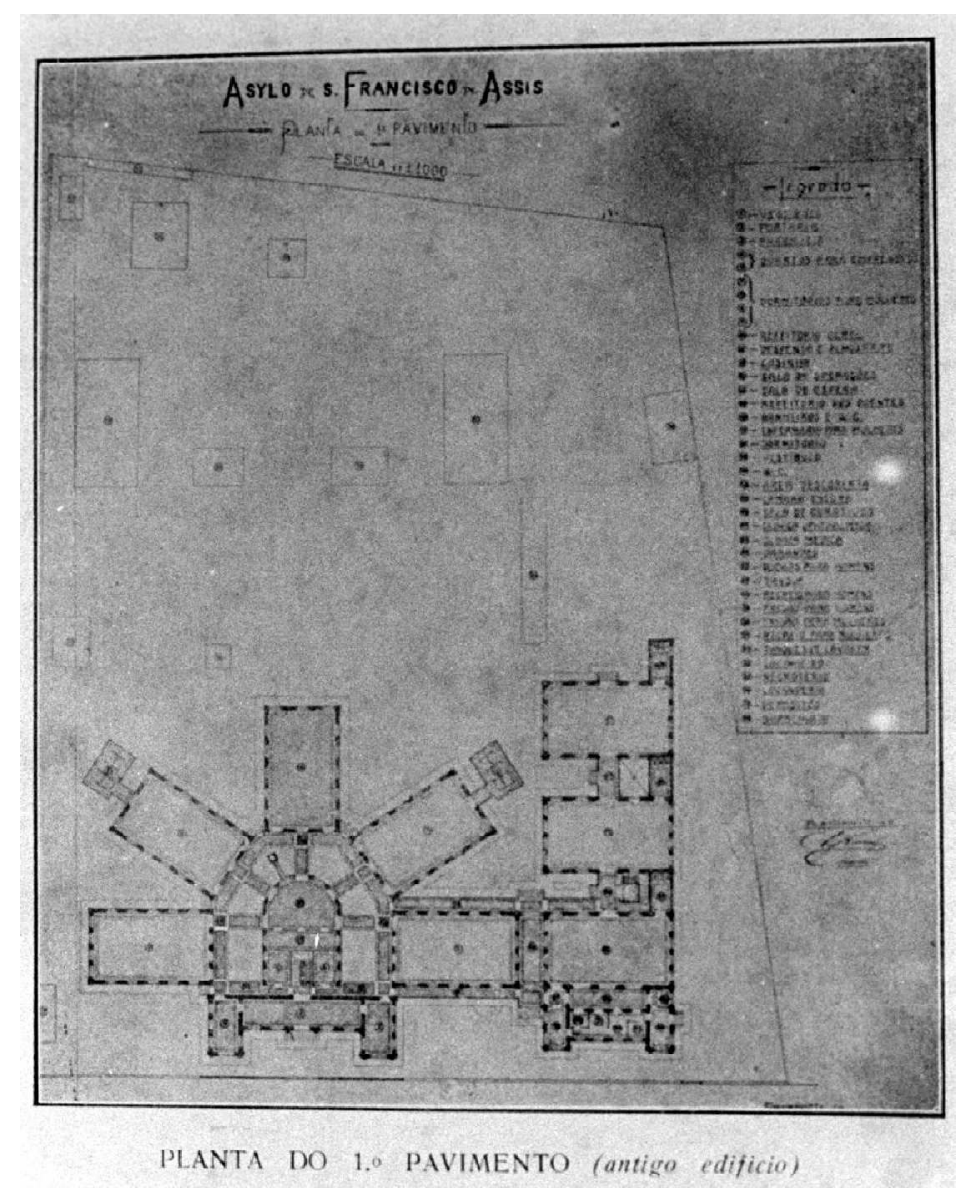

Figura 4 - projeto do edifício suplementar, parcialmente executado, de data desconhecida Fonte: ASSISTÊNCIA, 1922.

Em 1888, foi nomeada comissão pelo Ministério da Justiça para elaboração de um Plano Geral de Assistência Pública o qual resultou na construção de dois estabelecimentos - a Casa São José para os menores e a Colônia de Alienados do Galeão que ajudaram a aliviar a superlotação do Asilo (ASSISTÊNCIA, 1922). Porém, o recorrente envio de menores e alienados, além dos mendigos, manteve a situação calamitosa da instituição. Na década de 1880, com base nas denúncias feitas pelo Dr. J. C. Teixeira Brandão em seu livro Os alienados no Brazil, os jornais condenavam as condições do asilo: 
Loucos e não loucos, vagabundos e ociosos, mendigos e preguiçosos, homens e mulheres, velhos e crianças, lançados para alli a esmo, alli vivem n'uma promiscuidade abjecta e immunda, n'uma convivencia torpe e immoral! Aquelles miseros portadores de andrajos, exhalando de si um cheiro nauseabundo, misturam-se n'uma confusão horrenda e repugnante, casandose perfeitamente a indifferença dos que perderam effectivamente a razão com o cynismo dos que apenas perderam a noção da moral, da sociedade, do trabalho, da justiça, do dever, de tudo! A atmosfera da casa empesta; empestam as relações dos reclusos entre si, e aos quaes tudo falta - até água para se banharem! Inconscientes, os privados da razão; resignados, os verdadeiros mendigos; indiferentes, os que a ociosidade encaminhou para ali; vivem todos na comunhão da mais baixa miséria, tendo por leitos - taboas sem colchões nem travesseiros; por moveis nas suas salas - as cloacas de que se servem; por coberturas - os próprios trapos e andrajos que não os resguardam do rigor da estação invernosa, nem sequer lhes ocultam a nudez aos olhos dos seus companheiros de degradação! [...] Nem se póde conceber que entre nós exista estabelecimento tão degradante, tão deprimente do nosso adiantamento social, e de mais a mais - creado pelos nossos governos e administrado por nossas autoridades; um estabelecimento que o medico, a que nos referimos [Dr. J. C Teixeira Brandão], denomina - a ante-camara dos cemitérios, e que nós francamente denominamos: - o matadouro dos alienados. Um traço final para a exposição d'este quadro lúgubre e profundamente lamentável: a mortalidade no Asylo de Mendicidade é enorme: de 400 reclusos, ali faleceram em um anno - 134 homens e 87 mulheres! Effectivamente, só admira que d'aquelles 400 não morressem 400 ! Dos mortos, a que se refere a estatística, 15 succumbiram... á inanição!!(OS ALIENADOS no Brazil, 1886)

Somente em 1895, foi reelaborado o regulamento, alterando ainda o nome de Asylo da Mendicidade para Asylo São Francisco de Assis. A admissão de internos foi restringida a maiores de idade em número de duzentos e cinquenta, metade para cada sexo, aos indigentes sem condições de garantirem sua sobrevivência e aos que solicitarem entrada comprovando falta de recursos. Para evitar o internamento indiscriminado que ocorria anteriormente, a entrada dos indigentes recolhidos pelo Chefe de Polícia deveria ser aprovada pelo diretor do Asilo e pelo diretor de Higiene e Assistência Pública.

Até 1922, quando foi transformado no Hospital Geral do Departamento Nacional de Assistência Pública São Francisco de Assis (Figura 5), o asilo continuou funcionando com muitas dificuldades, cumprindo sua dupla função de isolar o interno e, assim, proteger a sociedade da sua presença incômoda (SILVA JR, 2000). Embora desde a sua concepção tenha-se buscado os ideais de ordem, higiene e modernização, ao longo do tempo o edifício mostrou-se insuficiente e inadequado por diversos motivos como má administração, a expansão urbana em sua direção que acabou por inseri-lo em meio ao centro populoso, surgimento de novas concepções que 
diferenciavam o asilo de uma prisão ou depósito e propunham atividades e oficinas para os internos às quais o edifício não estava adaptado e, principalmente, a impossibilidade de apenas ele resolver um problema tão grande e complexo quanto a mendicidade.

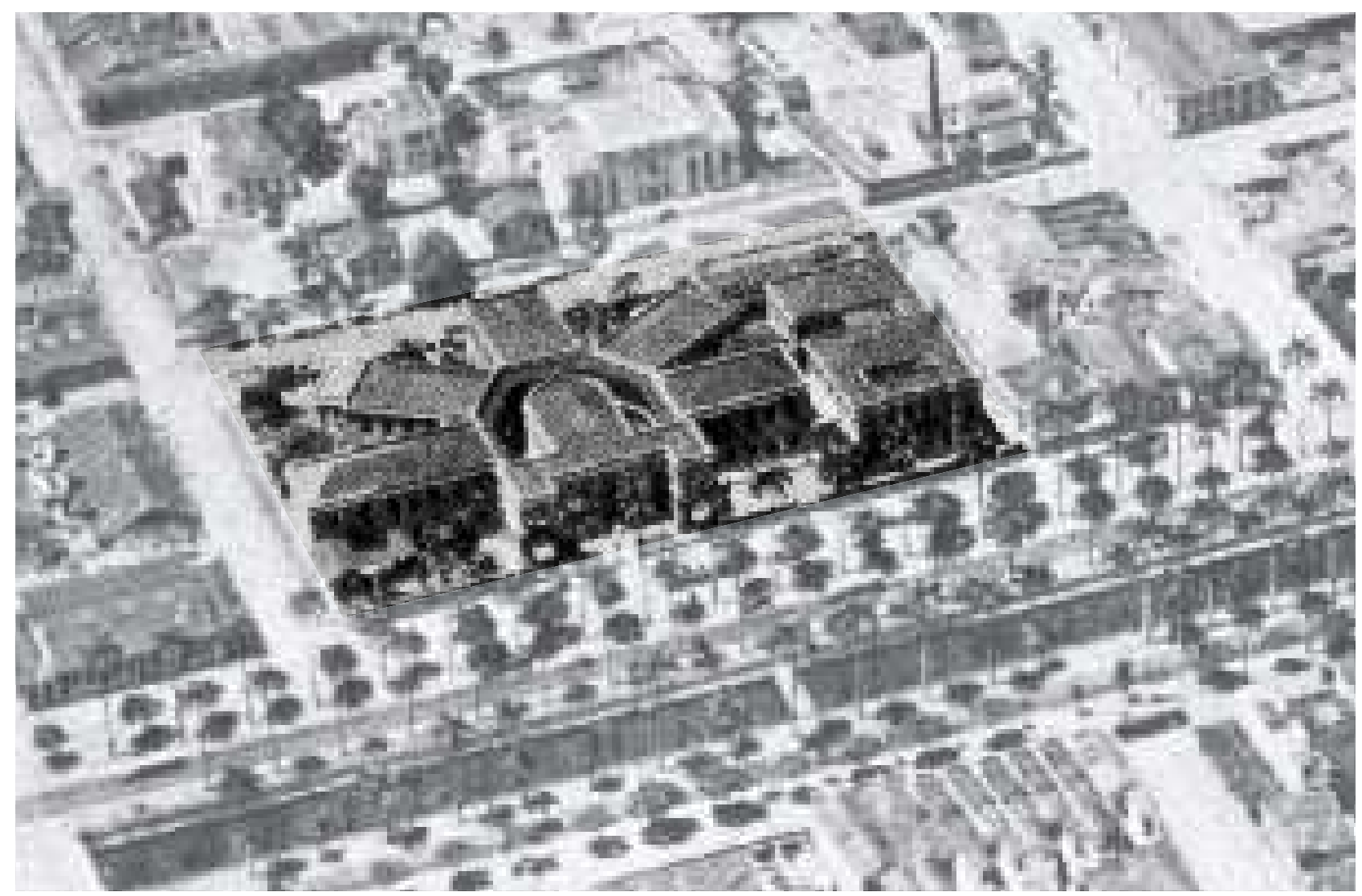

Figura 5 - Edifício em 1930, figurando o pan-óptico e o edifício suplementar.

Fonte: adaptado de FREIRE, 2004

\section{Referências}

ABREU, M. de A. Cidade Brasileira: 1870-1930. In: 8 Encontro de Geógrafos da América Latina, 2001, Santiago do Chile. 8 Encuentro de Geografos de América Latina. Santiago de Chile: Universidad de Chile, 2001. Disponível em: < http://observatoriogeograficoamericalatina.org.mx/egal8/Geografiasocioeconomica/G eografiaurbana/62.pdf >. Acesso em: 03 ago. 2013.

AGUinAgA, H. Hospital São Francisco de Assis: História. Rio de Janeiro: Companhia Brasileira de Artes Gráficas, 1977.

A MENDICIDADE. Diário do Rio de Janeiro, Rio de Janeiro , 21 out. 1856, p. 2.

ANDREATTA, V. Cidades quadradas, paraísos circulares: os planos urbanísticos do Rio de Janeiro no século XIX. Rio de Janeiro: Mauad X, 2006. 
Atlas Andreatta: atlas dos planos urbanísticos do Rio de Janeiro de Beaurepaire-Rohan ao Plano Estratégico. Rio de Janeiro: Vivercidades, 2008.

ASSISTÊNCIA Pública e Privada no Rio de Janeiro (Brasil): história e estatística. Rio de Janeiro: Prefeitura do Distrito Federal, 1922.

ASYLO de mendigos. Jornal do Commercio, Rio de Janeiro, 8 ago. 1876, p. 3.

BenCHIMOL, J. L. Pereira Passos: Um Haussmann tropical. A renovação urbana da cidade do Rio de Janeiro no início do século XX. Rio de Janeiro: Secretaria Municipal de Cultura, Turismo e Esportes, Departamento Geral de Documentação e Informação Cultural, Divisão de Editoração, 1992.

. Rio de Janeiro: da urbe colonial à cidade dividida. In: PINHEIRO, A. I. D. F.

Rio de Janeiro: cinco séculos de história e transformações urbanas. Rio de Janeiro: Casa da Palavra, 2010. p. 163-203.

BENTHAM, J. O Panóptico. Belo Horizonte: Autêntica, 2000.

BLAKE, A. V. A. S. Diccionario Bibliographico Brazileiro. Rio de Janeiro: Typographia Nacional, v. I, 1883.

BRASIL. Lei n.o 2.670, de 20 de Outubro de 1875. Disponível em: < http://www2.camara. leg.br/legin/fed/lei/1824-1899/lei-2670-20-outubro-1875589144-publicacaooriginal-116850-pl.html > Acesso em: 29 mai. 2013.

CHALHOUB, S. Cidade febril: cortiços e epidemias na Corte imperial. 4. ed. São Paulo: Companhia das Letras, 2006.

ESCÂNDALO. Diário do Rio de Janeiro, Rio de Janeiro, 25 jul. 1852, p. 3.

FOUCAULT, M. Vigiar e punir: história da violência nas prisões. 29. ed. Petrópolis:

Vozes, 2004.

FREIRE, E. Plano Diretor para o Hospital Escola São Francisco de Assis. Rio de Janeiro, 2004.

MACHADO, R. et al. Danação da Norma: Medicina Social e Constituição da Psiquiatria no Brasil. Rio de Janeiro: Edições Graal, 1978.

MORAIS, S. S. A arquitetura das estações ferroviárias da Estrada de Ferro Central do Brasil no século XIX: 1858-1900. 2002. Dissertação (mestrado) Programa de Pós-graduação em Arquitetura, Faculdade de Arquitetura e Urbanismo, Universidade Federal do Rio de Janeiro, Rio de Janeiro, 2002.

OS ALIENADOS no Brazil. Gazeta de Notícias, Rio de Janeiro, 26 dez. 1886, p. 1. PEREIRA, M. D. S. O Rio de Janeiro no século XIX: cenários, formas e virtudes de uma cidade-capital. In: PINHEIRO, A. I. D. F. Rio de Janeiro: cinco séculos de história e transformações urbanas. Rio de Janeiro: Casa da Palavra, 2010. p. 127-161. 
PEREIRA, S. G. O ensino de arquitetura e a trajetória dos alunos brasileiros na École des Beaux-Arts em Paris no século XIX. In: PEREIRA, S. G. 185 anos da Escola de Belas Artes. Rio de Janeiro: PPGAV/EBA/UFRJ, 2002. p. 93-177.

PINTO, F. M. A invenção da Cidade Nova do Rio de Janeiro: agentes, personagens e planos. 2007. Dissertação (mestrado) - Instituto de Pesquisa e Planejamento Urbano Regional, Universidade Federal do Rio de Janeiro, Rio de Janeiro, 2007.

PRISÕES, Extracto do Relatório do Ministério da Justiça, Reforma Penitenciária. A Nação, Rio de Janeiro, 28 mai. 1875. Peças Officiaes, p. 2.

RABHA, N. M. de D. C. E. Rio, uma cidade e seus planos. In: PINHEIRO, A. I. D. F. Rio de Janeiro: cinco séculos de história e transformações urbanas. Rio de Janeiro: Casa da Palavra, 2010. p. 205-229.

SEGAWA, H. Ao amor do público: jardins no Brasil. São Paulo: Studio Nobel: FAPESP, 1996.

SILVA JR., O. C. da. Do Asylo da Mendicidade ao Hospital Escola São Francisco de Assis: A Mansão dos Pobres. Rio de Janeiro: Papel Virtual Editora, 2000.

SILVA, L. Memórias do urbanismo na cidade do Rio de Janeiro 1778/1878: estado, administração e práticas de poder. Rio de Janeiro: E-papers, 2012.

SOBRAL FILHA, D. D. Lazer, Saúde e Ordem: Principais programas desenvolvidos na arquitetura do século XIX no Rio de Janeiro e no Recife. 2009. Dissertação (mestrado) - Programa de Pós-graduação em Arquitetura, Faculdade de Arquitetura e Urbanismo, Universidade Federal do Rio de Janeiro, Rio de Janeiro, 2009.

TELLES, P. C. da S. História da Engenharia no Brasil: Séculos XVI a XIX. Rio de Janeiro: LTC, 1994.

VIDLER, A. The writing of the walls. Princeton: Princeton Architectural Press, 1987. 